\title{
LIMINAL SPACES: LITERAL AND CONCEPTUAL BORDERLINES IN WHITMAN'S CIVIL WAR POEMS
}

\author{
JOAN R. WRY
}

In an 1865 LetTer to William Douglas O'Connor, Walt Whitman explained what he felt he had accomplished in a collection of Civil War poems, the as yet unpublished text Whitman thought was "more perfect as a work of art" than any of his previous publications:

Drum-Taps ... delivers my ambition of the task that has haunted me, namely, to express in a poem ... the pending action of this Time $\mathcal{E}$ Land we swim in, with all their large conflicting fluctuations of despair \& hope, the shiftings, masses, \& the whirl \& deafening din . . . with unprecedented anguish of wounded \& suffering . . \& then an undertone of sweetest comradeship \& human love, threading its steady thread inside the chaos, \& heard at every lull \& interstice thereof. (Corr, 1:246-247)

In this single passage Whitman defines his desired role as the lyric interpreter of the Civil War, positioning himself in the lines and spaces between the war's "large and conflicting fluctuations," and promising to thread compassion inside chaos through lines of poetry. These poems would call attention to the lulls and interstices of the "Time \& Land" of nineteenth-century America at war with itself, and in them Whitman's evolving persona gives voice to the conflicting perspectives of despair and hope. When his collection was finally published (and subsequently reprinted as a more cohesive and polished version in the 1871 edition of Leaves of Grass), it included over forty poems addressing a series of wartime spaces, transitions, and passages, many of which can be read as an attempt to position the extremes of war within human contexts, and ultimately within regenerative patterns in the natural world. ${ }^{2}$

These poems yield new insights when read specifically in the context of liminality, a cultural discourse that calls attention to margins and borderlines as transitional points but also focuses specifically on the "limen" or the spaces between, as literal and conceptual sites of potential and illumination. Anthropologist Victor Turner first referred 
to the concept of liminality in the 1970's after reading Arnold van Gennep's 1908 Rites de Passage, in which the transitional or interstitial phase in a rite of passage is identified as the "limen," a Latin word meaning "threshold." Turner subsequently defined the liminal phase or space as "an interval, however brief, when the past is momentarily negated, suspended, or abrogated, and the future has not yet begun, an instant of pure potentiality when everything, as it were, trembles in the balance." Turner suggests that liminality provides a catalyst for the creative impulse; it frequently generates "myths, symbols, rituals, philosophical systems, works of art. These cultural forms provide ... a set of templates, models or paradigms which are . . periodical reclassifications of reality . . . they incite [us] to action as well as to thought." ${ }^{3}$ It is specifically in this context that Whitman saw his role as lyric interpreter of the war, and a number of the Civil War poems engage liminal spaces in varied ways to render and instruct readers about the realities of war.

George Hutchinson's 1986 text, The Ecstatic Whitman: Literary Shamanism and the Crisis of the Union, offers perhaps the most insightful interpretations of Whitman's liminal interpretations of the war, and Hutchinson's argument that Whitman's career is best read as "a form of ecstatic prophetism" is impressively sustained by insights on Turner's theories and their intersection with literary shamanism. In defining Whitman's role and explicating the war poems, Hutchinson draws most significantly on communitas, defined by Turner as "a relational quality of full unmediated communication, even communion, between definite and determinate identities" (Turner, 250). Turner's communitas, Hutchinson argues, "posits the existence of 'anti-structure,' a liminal element, free and unbound by social norms," and it is here "we would find Whitman, the 'solitary singer,' in the limen, in communitas." Hutchinson explains further that "the great 'liminal' moments of history," such as the Civil War, often produce the emergence of a shaman or "individual visionary" who identifies and communicates "the solutions to community problems with which the 'church' or 'establishment' seems ill-equipped to deal." Moreover, Hutchinson is convinced that "Whitman clearly perceived himself in this light"-as a shaman reinforcing "social unity while exploring social problems and proposing solutions and prophecies." Consciously or unconciously, Whitman was "the prototype of the prophet of revitalization" (Hutchinson, xxv).

Whitman may well have desired this role, but as a poet he is a better exemplar of the border aspects of liminality than of the reciprocal engagement and "full unmediated communication and communion" of liminal communitas. Whitman witnessed the war from its literal and conceptual borderlines. He did not directly engage in battle, although he rendered others' accounts with photographic verisimilitude. He 
mediated almost exclusively in hospital interiors, as opposed to bloodied battlefields. What Hutchinson calls, following Turner, an "original experience of 'communitas' - a heightened sense of union among group members coinciding with ritual or revitalization" (Hutchinson, xxvii), is only a desired sense of union on Whitman's part. His war poems often have a wistful or voyeuristic quality on the edge of the war's outlines. That Whitman's war poems mediate in liminal ways is unmistakable - and Hutchinson's conception of the poet as mediator between the triadic structure of poet, audience, and spiritual world is a seminal contribution to this line of thinking-but Whitman's liminal role does not sustain the reciprocal communication and social unity of Turner's communitas. ${ }^{5}$ Rather, Whitman addresses the literal and conceptual borderlines of the war with three degrees of engagement, notwithstanding a potential desired endpoint of revitalization and social unity-a visionary communitas perhaps one day possible in the fully-emerged democracy that could appear in some post-war future.

Still, even the margins and borderlines are sites of productive inquiry, and in those liminal spaces and interstices Whitman illuminated the varied realities of the Civil War as he proffered ministry and mediation to his audiences. The intended recipients of Whitman's mediation included soldiers as well as the families who received the letters and messages he exchanged on the soldiers' behalf, but the mediation also addresses the past, present, and future readers of his poetry. In a sense, there is a timeless quality to Hutchinson's triadic structure of the poet, audience, and spiritual world, but there are other three-part structures possible in liminal discourses as well. I would suggest that at the most basic level, as evidenced in the more photographic poems, liminality provides Whitman with a framing technique, allowing him to sharpen his focus on the verisimilitude of a scene by delineating the outlines and interstices of the natural landscape. A second, intermediate use of liminality calls attention to hospital spaces as literal and figurative symbols of transition for wounded or dying soldiers, spaces in which Whitman as witness and healer positions himself at the center of those liminal interiors. A third, mystical use of liminality allows Whitman to further define his role as an interpreting agent from the borderlines and margins of the war, the poet who gives meaning to the ultimate passage from life into death for all the nation's dead.

Consider Whitman's attention to liminal spaces as demarcating borderlines or margins in the more photographic poems in the collection, poems such as "Cavalry Crossing a Ford," "Bivouac on a Mountainside," and "An Army Corps on the March." Whitman's biographers have pointed out that the rendered scenes in these poems are drawn from both the eyewitness recollections of the wounded soldiers 
Whitman cared for in wartime hospitals as well as from newspaper accounts, sometimes using the exact language of newspaper telegraphic dispatches. ${ }^{6}$ Despite the obvious journalistic parallels (and despite the physical absence of Whitman as witness), these poems offer the pointblank-range perspective of a persona fixed on the landscape, producing a mise-en-scène in which boundary lines are emphasized with photographic verisimilitude. ${ }^{7}$ In a sense, attention to boundaries would seem to be counterintuitive for a fluid, boundless, and "absorbing" poet like Whitman, but as an inheritor of Emerson's transcendentalism Whitman was drawn to points of transition in the natural landscape. As Garry Wills notes of this charged period in American history at roughly the century's midpoint: "The borderlines (limina) in nature appealed to people who saw, figured there, the great limits to knowledge, and time and history that they were meant to transcend ... margin was [for them] a charged word, whether used of a field, lake, petal, or cloud" and "the edge of the wilderness gave meaning both to civilization and virgin nature." 8

Margin was a charged word for Whitman-literally as it applies in these photographic poems, but also conceptually in his attentiveness to the marginalized and nameless, the unknown soldiers who served and died in the ranks. ${ }^{9}$ In "Cavalry Crossing a Ford," for example, men and horses form a visual borderline winding "betwixt green islands." The scene is imbued with reflected light, both from the sun above and the "silvery river" below; it flashes on the metal blades and barrels of weapons and shines on the distinct features of "brown-faced men ... each person a picture" $(L G, 300)$. In an expanse of seven lines, the inanimate "line in long array" becomes notably alive, the human faces of war illuminated in the liminal space between the banks of the river, moving fluidly from point to point in a framed scene. In "Bivouac on a Mountainside," the human borderline ceases movement, "halting" at midpoint against a terraced mountainside framed by a fertile valley below and the over-arching sky and eternal stars above. Again, a liminal context illuminates distinct and individual animations as shadowy flickering forms of men and horses become visible in the "scatter'd" light of campfires $(L G, 300)$. In "An Army Corps on the March" the line resumes the advance, the corps "glittering dimly" in this fixed scene as "dust-cover'd men, / In columns rise and fall to the undulations of the ground" ( $L G, 301)$. These poems are Whitman's war photographs - or, perhaps more appropriately, his lyric canvases. Even in the most direct reproductions of the natural landscape they emphasize the human undertones of connection threading its threads, to use the language of Whitman's earlier cited letter, inside the chaos of war. In these poems (and others like them), the soldiers themselves fill the interstices in the "lulls" between battles. Viewed collectively, they 
often form literal borderlines on the landscape; positioned in liminal configurations of physical space, they reveal individual human contexts in the face of war's harsh realities.

Somewhat ironically, Whitman's earliest war poems reveal very little of the human face of war, except in idealized form. In the poem "1861," for example, the single soldier of focus is a "strong man erect . . . with well gristled body" and "sinewy limbs" and his "shouting . . . sonorous voice ring[s] across the continent" ( $L G, 282-283)$. In "Song of the Banner at Daybreak," the Poet "hear[s] the jubilant shouts of millions of men" and exults in the final section: "My limbs, my veins dilate, my theme is clear at last" ( $L G, 287,290)$. But in spite of his professed mediating role in lines 13-14 ("I'll weave the chord and twine in . . I'll put in life"), Whitman has not yet clarified either his theme or his interpretive role in the early war poems. As Harold Aspiz notes, these first poems are "filled with enthusiasm for war"; they embody "the popular concept that war will promote national unity-Hegel's principle that 'by arousing the passions of solidarity and transcendence, war makes nations, or at least revives and refreshes them."'10

In another early poem, "The Centenarian's Story," Whitman attempts to fuse a photographic focus on the landscape's borderlines with a heavy-handed projection of himself as lyric interpreter of two different wars. Luke Mancuso describes "The Centenarian's Story” as "a nostalgic bridge-poem to the Revolutionary War Battle of Brooklyn"; the poem is set in an 1861 training camp where a "decisive Revolutionary battle" was fought on the same landscape " 85 years earlier."11 Whitman's persona invites the aged veteran of the Revolutionary War to "speak in your turn," and promises that as poet-persona he will "listen and tell" ( $L G, 295)$. Whitman then recounts the borderlines of the Centenarian's "same ground," the "lines of rais'd earth stretching from river to bay," allowing the veteran to frame the battle scene from that earlier war: "I mark the vista of waters, I mark the uplands and slopes" $(L G, 296)$. When the battle account concludes, the poet notes his achievement: "The two, the past and present, have interchanged, / I myself as connector, as chansonnier of a great future, am now speaking" ( $L G, 299)$. But Whitman's mediation between two wars linking past and present is here only a desired "interchange"; in other poems the physical spaces of wartime hospitals will allow Whitman to more fully develop his mediating role, even if he is still considerably distanced from battlefield immediacy. In Specimen Days, Whitman describes his positioning of the hospital as a liminal symbol during the war: "it seem'd sometimes as if the whole interest of the land, North and South, was one vast central hospital, and all the rest of the affair but flanges."12 In this space between flanges Whitman considers a more definitive purpose for 
his poetic voice, and hospital spaces provide the literal and conceptual borderlines framing the lyric project.

Wartime hospitals are liminal spaces for the wounded who either pass from life to death within their walls, or (less frequently) emerge stabilized or healed. It was not until Whitman visited his wounded brother at Fredericksburg, Virginia, that he was able to understand war in light of specific and individual contexts, and perhaps more importantly, render those contexts in lines of poetry. After accompanying a medical team bringing casualties from Fredericksburg to Washington and witnessing the bloodied aftermath of the battle, Whitman committed himself to the self-appointed role of "wound-dresser," tending to the physical and spiritual wounds of the injured and dying in hospital wards for the remainder of the war. ${ }^{13}$ That Whitman saw himself in a mediating role is unmistakable; he positioned himself conceptually between the wounded soldiers and their battlefield experiences, serving witness to their suffering and fear through the language of poetry.

George Hutchinson cites a letter Whitman wrote to Margaret Curtis to note the particular liminal positioning of the poet's hospital ministries, quoting Whitman's characterization of himself as "particularly useful to patients 'who are ... trembling in the balance, the crisis of the wound, recovery uncertain, yet death also uncertain ... I think I have an instinct \& faculty for these cases"' (Hutchinson, 137). As Hutchinson notes of the "shamanistic disposition" of Whitman's calling: "Whitman became the sort of 'mystical healer' he had hoped to be ... [and] considered the heart of the national crisis to be concentrated in the hospitals; his own role there was vitally connected, in his own mind, with his ministrations to the Union" (Hutchinson, 137, 138).

In the final stanza of the poem "The Wound-Dresser," for example, Whitman calls upon the liminal space of dreaming for a scene "concentrated" in a hospital setting; there he recreates an intensive past moment of ministry through a recalled dream rendered in language. "Liminal experiences [such as] twilight, dreams, daydreaming melancholy, premonitions - are not fuzzings" or blurrings of experience, Garry Wills notes, but rather "intensifications of knowledge" (Wills, 73). Whitman's dreaming persona "threads" himself through the interstices of hospital rooms in the final stanza of this poignant recollection:

Thus in silence in dreams' projections,

Returning, resuming, I thread my way through the hospitals,

The hurt and wounded I pacify with soothing hand,

I sit by the restless all the dark night, some are so young,

Some suffer so much, I recall the experience sweet and sad. $(L G, 311)$ 
Hutchinson additionally points out that one of the motifs "derived from Whitman's shamanistic stance include[s] the framing of war episodes within dreams or visions" (Hutchinson, 139) that often feature highly ritualized processions or liturgical movements. In the poem, "A March in the Ranks of the Hard-Prest, and the Road Unknown," Whitman combines the contexts of literal margins and borderlines in nature with the conceptual liminal space of a makeshift place of healing-in this case, a church converted into hospital space at a liminal intersection. A line of marching soldiers wearily traverses a "road unknown [. . . a route through a heavy wood" only to come unexpectedly upon "an open space in the woods" where an "old church at the crossing roads" now serves as an "impromptu hospital" ( $L G, 305)$. Transitioning into this space (after literally crossing the threshold or limen of the doorway), the persona experiences an intensification of knowledge: "Entering but for a minute I see a sight beyond all the pictures and poems ever made, / Shadows of deepest, deepest black." It is a scene of intensive carnage, a panoramic illumination of war's horrors paradoxically rendered in darkness.

The persona's focus is drawn to the dying soldier at his feet, a single human identity among the bodies of the living and the dead, and the undertones of compassion "thread inside the chaos" as the speaker tries to stop the boy's bleeding and then bends toward him just before the pausing soldiers are ordered to resume the march. The moment coincides with the transition from life to death, itself a liminal passage fixed in the image of the boy's eyes:

[I] hear outside the orders given, Fall in, my men, fall in;

But first I bend to the dying lad, his eyes open, a half-smile gives he me,

Then the eyes close, calmly close, and I speed forth to the darkness,

Resuming, marching, ever in darkness marching, on in the ranks,

The unknown road still marching. ( $L G, 306)$

Hutchinson observes that "the youth's death bears the aura of a benediction" in this poem, adding that "the procession that leads the poet through the church-hospital expresses intense communality and bears onward the liminal quality that emerges, indirectly, from [the poem's] drenched sacral atmosphere" (Hutchinson, 145). Hutchinson's "association of the hospital with the poet's ritual landscape" is impressively drawn, but the "express[ion] of intense communality" seems less appropriate in this sacred scene. The sole processionary figure standing out in the dream sequence is the persona-poet, and his singular focus is on the dying youth in the hospital interior. In a sense, the persona is on the borderline of the experience; he alone seems to leave the ranks to cross the threshold, "entering but for a minute." Moreover, the per- 
sona only "hear[s] outside the orders given," a command shouted from communitas beyond the walls of the sacred space. His ministrations are solitary-even in the midst of "the crowd of the bloody forms" ( $L G$, 305) - and directed to the wounded "who are . . trembling in the balance," to use Whitman's liminal language from his earlier-cited letter.

But the mediating role of the poet is not always in the context of healing and comforting the wounded or dying, and in other hospital poems Whitman is fixated upon the corpse as a liminal symbol between life and death. Jeff Sychterz notes that in Julia Kristeva's theorization of the abject, "the corpse exists as a 'strange' liminality that threatens the very boundaries . . . between here (meaning) and nowhere (meaninglessness)," and in this sense it exists as "the impossible, lying beyond borders, beyond language, beyond vision, and beyond representation." Sychterz concludes that in Whitman's poetry, "the corpse . . . confounds the abstract meanings that the poet had previously found in the Civil War-Democracy, Union, and brotherly Comradeship - threatening to reveal them as rhetorical illusions." But in calculating the "loss of transcendent meaning precipitated by the corpse" in the war poems, Sychterz fails to account for Whitman's ability to see the transcendent power of death as the ultimate liminal transition. ${ }^{14}$

Still, a dynamic comprised of mediating poet and mute corpses underscores the irony of what Hutchinson sees as Whitman's desire for "communion between the definite and determinate identities" in Turner's version of communitas. Hutchinson's triadic structure between the poet, the audience, and the spiritual world does allow the poet to hold "the key position in this triad, mediating between the other two referents of the performance, attending to their diverse demands,"even if this structure lies outside of full communitas (Hutchinson, $\mathrm{xx}$ ). In the poem "A Sight in Camp in the Daybreak Gray and Dim," for example, Whitman's mediating poet-speaker emerges from his tent at the transitional point of daybreak to see "three forms" on "the path near by the hospital tent" ( $L G, 306)$. "Untended" and fully covered by blankets, these corpses are to remain outside of the hospital space interiors. But Whitman attends to the referent of the human face of war in focusing on the transcendent meaning of each form in turn: first the "dear comrade," next the "sweet boy," and finally the "young man" with the "face of the Christ himself" ( $L G, 306-307)$. It is this third form that is "Dead and divine and brother of all" ( $L G, 307)$, and yet the syntax of this final line suggests that all three forms (now "divine" in spirit, yet linked corporeally in the brotherhood of death), have the same transcendent identity. In this sense, the corpse functions not as "a loss of transcendent meaning" but rather as a liminal marker of the transition between life and death, the corporeal locus of the spirit's crossing over into the realm of the transcendent. 
M. Wynn Thomas adds that Whitman's reverential attention to the corpses of soldiers expanded his ministry by allowing him to perform "as a surrogate mourner of the dead-one who took it upon himself to do what relatives could not do: to remember the dead man in the very presence of his corpse." 15 The poem, "Vigil Strange I Kept on the Field One Night," is, in Thomas's words, "a poem about mourning as well as a poem of mourning" (Thomas, 123), but Whitman's use of mystical language and his emphasis on symbolic ritual also mark this battlefield burial as a definitive rite of passage. Whitman admittedly saw the full expanse of the Civil War as liminal for the nation's emerging democracy, but difficult rites de passage routinely occurred in singular battlefield moments, such as the one commemorated in "Vigil Strange." Van Gennep warns of this jarring shift in states of being: "so great is the incompatibility between the profane and the sacred worlds, that a man cannot pass from one to the other without going through an intermediate stage" involving "liminal rites of transition." 16 The profane world of the battlefield threatens to subsume the death of the fallen soldier in this poem, but Whitman's "vigil of silence, love, and death" fills the liminal space of transition:

Long there and then in vigil I stood, dimly around me the battle-field spreading, Vigil wondrous and vigil sweet there in the fragrant silent night, [ . . ]

Passing sweet hours, immortal and mystic hours with you dearest comradenot a tear, not a word,

Vigil of silence, love, and death. (LG, 304)

"To cross the threshold is to unite oneself with a new world," van Gennep asserts (20), and while Whitman's death passage in this poem can be read in light of corporeal transcendence-the spirit's transition into some form of afterlife-it is important to note that the corpse itself (reverenced in the ritual of "immortal and mystic hours") is invested with symbolic and transcendent meaning. ${ }^{17}$ The persona ends the "vigil final" at the transitional point of daybreak ("indeed just as the dawn appear'd"), first carefully wrapping the corpse in a blanket that "envelop'd well his form," and then burying it in a battlefield grave "bathed by the rising sun" ( $L G, 304)$. Harold Aspiz notes that "enshrouding and burying the soldier's body transforms this death . . into a sacred action" (Aspiz 175), but it is the liminal spaces of daybreak and burial that allow Whitman to transcend the dark night of the battlefield and affect the transition from the profane to the sacred.

Thomas notes further that "a poem like 'Vigil Strange' cries out to be read against [a] background ... of the desire to ensure that the battlefield dead are individually recognized, remembered, and mourned" (Thomas, 125). In "Dirge for Two Veterans," Whitman focuses on 
the ceremonial aspects of the funeral march "down [to] a new-made double grave" for a fallen father and son, neither of whom are named, but whose passing is "recognized, remembered, and mourned":

I see a sad procession,

And I hear the sound of coming full-key'd bugles,

All the channels of the city streets they're flooding,

As with voices and with tears. $(L G, 314)$

As the funerary procession moves through the interstices of city streets, Whitman's persona marks the ceremonial sounds of the music and drums and acknowledges the "sooth[ing]" illumination of the moon on the horizon, "ascending / Up from the east" and then notes in the final lines his own contribution:

The moon gives you light,

And the bugles and the drums give you music,

And my heart, $\mathrm{O}$ my soldiers, my veterans,

My heart gives you love. $(L G, 315)$

Here Whitman voices the essential purpose of his lyric mediation: to thread human love and compassion through chaos and sadness, and to sound it at every lull and interstice on the wartime landscape. But Whitman was to reserve his greatest mediation of what van Gennep termed as the "incompatibility of the profane and the sacred worlds" for the historic and named rite of passage that followed the war. As George Hutchinson notes of the poem that commemorated "the assassination of the American Osiris" in the months that followed the ceasefire: "Lilacs' mediates both Lincoln's passage from life to death and the nation's passage from wartime to a peacetime identity" (Hutchinson, 150). In "When Lilacs Last in the Dooryard Bloom'd," Whitman fuses the ceremony of Lincoln's funerary procession with the mediating insights of death as the ultimate rite of passage; he also "completes the rite of passage and purification symbolized in the historic event" of the Civil War, as Hutchinson observes in his impressive explication of "Lilacs." 18

First published in the sequel to Drum-Taps, the poem is replete with borderlines, margins, and images of transition; even the three recurring symbols of lilac, thrush, and western star are representative of liminality in the way they juxtapose life and death, or more specifically engender life out of death. The lilac with its "heart-shaped leaves" is a flower of mourning (the persona places a lilac sprig atop Lincoln's coffin) and yet it signals the transitions and new life of spring with its "many a pointed blossom rising delicate," and "every leaf a miracle" ( $L G, 329)$. The thrush "sings Death's outlet song of life" from its "Bleeding throat," entwining life and death; its recurring image on nineteenth-century 
headstones symbolized death, but also the flight of the soul into the afterlife.$^{19}$ The western star appears in the liminal space of twilight to symbolize the deceased Lincoln's "prescient spirit" in section 8, but it is also" the "ever-renewing star that emerges in spring" (Aspiz, 197), the star that marks the end of the winter sky. Even Lincoln's coffin threads its steady thread through the landscape interstices of a nation in mourning, "passing the endless grass, / Passing the yellow-spear'd wheat, every grain from its shroud in the dark-brown fields uprisen . . . / pass [ing] through lanes and streets, / Through day and night with the great cloud darkening the land" ( $L G, 330)$.

Whitman's earlier referenced task of expressing in a poem "the pending action of this Time and Land we swim in, with all their large conflicting fluctuations of despair and hope," is perhaps most fully realized in this poem in the pivotal dream sequence of section 14. Whitman places himself in a literal and conceptual liminal space in these lines - as persona, he is the literal middle figure positioned between two companions in the dream sequence, and as poet, he is the conceptual mediator of the mystery of life into death. The section opens in the "large unconscious scenery" of the American landscape at the transitional points of "the close of day" with "summer approaching," and the focus is on the animated rhythms of human experience: "voices of children and women," the "busy . . labor" of fields, the "minutia of daily usages" in households, the "throbbings" of city streets $(L G$, 333-334), all observations Whitman's poet-persona makes from his borderline positioning in the scene.

In the middle of this vibrant animation the charged symbol of the cloud "appear'd," and with it "appear'd the long black trail." The repeated use of the verb "appear'd" emphasizes the suddenness of death's coming forth in the midst of life, and the poet names this reality instantly: "And I knew death, its thought, and the sacred knowledge of death" $(L G, 334)$. But the larger task is interpreting this reality in language that will convey the "pending action" of life into death, and Whitman offers a liminal dream-parable to instruct the mystery:

Then with the knowledge of death as walking one side of me, And the thought of death close-walking the other side of me,

And I in the middle as with companions, and as holding the hands of companions, I fled forth to the hiding receiving night [ . . . ]

Down to the shores of the water, the path by the swamp in the dimness. $(L G, 334)$

The mediating poet-persona walks the literal borderline between his companions" "knowledge of death" and "thought of death," and in his liminal role as interpreter, he serves as the space between grieving thoughts of death as an end point, and a subsequent knowledge of a larger and more cosmic awareness of death as a transition, the "sacred 
knowledge of death." The rest of section 14 is fluid and moving; the thrush returns to sing a death song as the three companions move from the shores of the dark swamp to larger transitional waters: death's "loving floating ocean" $(L G, 335)$. The swamp in this dream sequence is, as Harold Aspiz notes, "a realm of darkness and decay," but it is also a "place of metamorphosis - a realm in which death and decay perpetually nurture life and renewal" (Aspiz, 201).

Whitman's insights into death's mystery, his attempts to mediate and explain the journey into an "unknown realm that may lie beyond mortality" (Aspiz, 205), is still heavily burdened by the Civil War, however, for shortly after the lyric sequence of mystical insight the speaker is overwhelmed in section 15 by visions of wartime atrocities, first seen "askant," and then directly: myriad "battle-corpses [ . . ] / white skeletons [ . . ] / debris of all the slain soldiers of the war" ( $L G$, 336). In the final section of the poem, the persona awakens, "passing" from night and visionary walks to the daylight realities of Lincoln's death and the war's toll on the still grieving nation. Yet even in grief there are compensatory moments, "retrievements out of the night," $(L G, 337)$, the visions and songs in liminal spaces that provide intensifications of knowledge. In the final lines of the poem, Whitman's persona notes, "Comrades mine and I in the midst, and their memory ever to keep," but his liminal positioning falls short of literal communitas as he mediates only the memories of the dead. Still, these are also "retrievements out of the night," and from the borderlines and margins of liminal experience Whitman addresses the task that had long haunted him-expressing the time and land of the nation in lines of poetry.

In his 1997 text, The Wreath of Wild Olive, Mihai Spariosu asserts that "liminal time-space can lead to an irenic [non-polemical] mentality that transcends all violent conflict." Since the "idea of agon or contest lies at the foundation of the Western philosophy of difference," Spariosu notes, liminal spaces are important in that they provide "thresholds or passageways allowing access to alternative worlds." ${ }^{20}$ In these spaces, the peace-seeking, "irenic" mentality will not "experience difference as a conflict, but rather as an openness and an opportunity toward a responsive understanding of other worlds" (Spariosu, 119). In the poem "Camps of Green" Whitman acknowledges the two worlds he "threads" between: "Lo, the camps of the tents of green, / Which the days of peace keep filling, and the days of war keep filling, / With a mystic army" $(L G, 499)$, and he again sketches the borderlines of dichotomy in the poem "So Long!": "I have press'd through in my own right, / I have sung the body and the soul, war and peace have I sung, and the songs of life and death" (LG, 503).

In the final poem of the Drum-Taps/Sequel collection, "To the Leaven'd Soil They Trod," Whitman's mediating persona claims "I sing 
for the last, / (Forth from my tent emerging for good," acknowledging the response of "The average earth, the witness of war and peace" (LG, 326-327). But Whitman was to sing of the war well beyond the original Drum-Taps collection, ${ }^{21}$ threading irenic lines of communication through war's chaos and its aftermath. In "Songs of Parting" (the cluster of poems that includes "So Long!" and "Camps of Green"), Whitman's short poem "Portals" asserts the power of liminality in two somber lines: "What are those of the known but to ascend and enter the Unknown? / And what are those of life but for Death?" $(L G, 502)$. Clearly, the portals opened by Whitman as the war's interpreter reveal truths both about the human face of war and the meaning of death as the ultimate rite of passage, the transition into the afterlife. ${ }^{22}$ The idea of liminal transcendence is clear in "Joy, Shipmate, Joy!," another poem from "Songs of Parting," one that looks past wartime chaos to the voyage and life that lies beyond:

Joy, shipmate, joy!

(Pleas'd to my soul at death I cry,)

Our life is closed, our life begins,

The long, long anchorage we leave,

The ship is clear at last, she leaps! $(L G, 501)$

In the poems of Drum-Taps and later collections, Whitman bears witness to nineteenth-century America at war with itself, interpreting with language commensurate to what he called the "large, conflicting fluctuations of despair and hope." In "Not Youth Pertains to Me," Whitman summarizes his far-reaching role as a compassionate mediator, ministering to the dying he once characterized in a letter as "trembling in the balance" of a specific time and land:

I have nourish'd the wounded and sooth'd many a dying soldier,

And at intervals waiting or in the midst of camp,

Composed these songs. $(L G, 319)$

That Whitman could thread human compassion in the midst of war's "waiting intervals" can yet serve as a modern paradigm for individual responses to military conflict, even when the borderlines between life and death may seem no more than distant abstractions. In the limen of the present moment, to use Victor Turner's words, "everything, as it were, trembles in the balance" (Turner, 41), and in these spaces Whitman teaches us through language to find the human face of war, even in the transitional moments between death and the spaces beyond.

Saint Michael's College 
In honor of Professor fohn Reiss (1935-2008), whose beloved memory will always give me "retrievements out of the night."

\section{NOTES}

1 Harold Aspiz quotes Whitman's characterization of the "more perfect" collection and the text of the letter to O'Connor in So Long! Walt Whitman's Poetry of Death (Tuscaloosa: University of Alabama Press, 2004), 163-164. Aspiz describes Whitman's letter as "shed[ding] a valuable light on what the poet intended to achieve in his war poems" (163). For the complete text of the letter, see The Correspondence, ed. Edwin Haviland Miller (New York: New York University Press, 1961), 1:246-248.

2 Whitman's Civil War poems include the above referenced collection Drum-Taps, but also the Sequel to Drum-Taps and select poems from "Songs of Parting." See Leaves of Grass: Comprehensive Reader's Edition, ed. Harold W. Blodgett and Sculley Bradley (New York: New York University Press, 1965).

3 See Victor Turner, Process, Performance, and Pilgrimage (New Delhi: Concept, 1969), 41, 50.

4 See The Ecstatic Whitman: Literary Shamanism and the Crisis of the Union (Columbus: Ohio State University Press, 1986). Hutchinson's introduction explicates communitas as the "anti-structural limen" through which Whitman attempts "to reveal his most essential message” (xxiv).

5 Hutchinson notes that one of the "virtues of the shamanistic model is that it provides a paradigm for the blending of narrative, dramatic, and lyric modes . . In the great ecstatic poems, as in shamanic performance, the dramatic situation is fundamental to the artist's discipline; this situation is triadic, involving relationships between the poet, the audience, and the spiritual world" (xx). Hutchinson skillfully applies certain aspects of Turner's "enactment of communitas" to Whitman's role in the war, noting for example, that "the communitas underlying all social bonds and achieved at certain points of ritual performance . . . is typically experienced in an antistructural landscape" where the poet "inhabits a status between or outside of structures" (xxiiixxiv). But Whitman is not emblematic of the "essential we" relationship Turner (and others) insist is intrinsic to the shared social bonds of communitas. For more on the intersection of Turner's theories with Hutchinson's varied readings of communitas in Whitman's war poems, see xx-xxvii.

6 See Ted Genoways, "Civil War Poems in 'Drum-Taps' and 'Memories of President Lincoln," ' in A Companion to Walt Whitman, ed. Donald D. Kummings (Malden, MA: Blackwell, 2006), 526-528, for line-by-line comparisons of "Cavalry Crossing a Ford" and "An Army Corps on the March" with 1864 dispatches from The New York Times.

7 Huck Gutman notes that the opening poems in Drum-Taps "exploit a mode of seeing associated with the discovery of photography. They possess the same visual clarity, the same precise focus, found in contemporary photographs of the war, such as those taken by Matthew Brady." See Gutman's "Drum-Taps," Walt Whitman: An Encyclopedia, ed. J.R. Lemaster and Donald D. Kummings (New York: Garland publishing, 1998), 190-193, for additional analysis of Whitman's "precise word-pictures of men at war."

8 Garry Wills, Lincoln at Gettysburg (New York: Touchstone, 1992), 73. 
9 Ties between margin and marginalization, social class, and liminality are further explored by Andrew Larson, Walt Whitman and the Class Struggle (Iowa City: University of Iowa Press, 2006); see pages 8-12 for Turner's identification of the lower middle class as "threshold people," many of whom would have comprised the ranks Whitman describes in Drum-Taps. Larson additionally notes that "Whitman declaimed the virtues of 'independent manhood' as represented by a particular person with a liminal class location" (11).

10 Harold Aspiz quotes Hegel as part of his analysis of Whitman's early war poems; see So Long! Walt Whitman's Poetry of Death, 165-166.

11 See Luke Mancuso, "Civil War," in A Companion to Walt Whitman, 302-303.

12 Prose Works 1892, ed. Floyd Stovall (New York: New York University Press, 1963), 1:117.

13 Paul Zweig ("The Wound Dresser," in Walt Whitman, ed. Harold Bloom [New York: Chelsea House, 1985], 154) states, "It is clear that the hospitals were vital places for Whitman. During four years, he rarely missed a day, with his knapsack full of gifts and his florid fatherliness. Even when the war was over, and the country labored to forget its four years' ordeal, Whitman went on visiting the chronic cases that lingered in a few outlying hospitals. He thrived as a bringer of comfort."

14 See Jeff Sychterz, "'Silently Watch(ing) the Dead': The Modern Disillusioned War Poet and the Crisis of Representation in Whitman's Drum-Taps," Discourse 25.3 (2003), 22-23.

15 M. Wynn Thomas, "Fratricide and Brotherly Love," Transatlantic Connections: Whitman U.S. / Whitman U.K. (Iowa City: University of Iowa Press, 2005), 123.

16 See Arnold van Gennep, The Rites of Passage (Chicago: University of Chicago Press, 1960) 1, 11.

17 Harold Aspiz notes that Whitman's Memoranda During the War "records his grief for the thousands of unknown soldiers ... who died alone or without proper burial, or whose fate remained unknown to their loved ones" (174). "Vigil Strange I Kept on the Field One Night" represents, according to Aspiz, "a ritual act of symbolic closure for the nation's unknown dead [;] . . . the word vigil, rich in sacred connotations, occurs eight times in the twenty-six line poem" (174).

18 See Hutchinson, 149-169, for a detailed explication of the poem; the quoted passages in this section appear on 149-150.

19 Aspiz notes the "song of the thrush embodies the allure that death has always had for the persona" (195); because of its frequent representation on cemetery headstones and its recognition as a symbol of the soul's flight, the thrush is one of the poem's "images that represent both death and renewal" (195).

20 Mihai I. Spariosu, The Wreath of Wild Olive: Play, Liminality, and the Study of Literature (Albany: State University of New York Press, 1997), 169-170, 32.

21 Ted Genoways states that Whitman's Civil War poetry "was a project he never completed, as he continually added new poems about the war and moved them ever more pervasively into the body of Leaves of Grass" (537). 
22 William Scheick notes that the afterlife is viewed in Whitman's poems not in "typical nineteenth-century Christian belief in an ascent to heaven," but rather a "thoroughly Transcendental understanding of the afterlife .... Throughout his poetry, Whitman's explicit and implied imagery of ascent conveys a Transcendentalist belief in the soul's ongoing and endless progression along successive orbits expanding infinitely" (338-339). See "Death and the Afterlife," A Companion to Walt Whitman, 325-340. 